\title{
Questes
}

\section{L'autorité de l'argument. Note à propos de la Somme théologique, Ia pars, q. I, a. 8}

\section{Xavier Kieft}

\section{(2) OpenEdition}

\section{Journals}

\section{Édition électronique}

URL : http://journals.openedition.org/questes/1553

DOI : 10.4000/questes. 1553

ISSN : 2109-9472

\section{Éditeur}

Les Amis de Questes

\section{Édition imprimée}

Date de publication : 15 janvier 2006

Pagination : 5-12

ISSN : 2102-7188

\section{Référence électronique}

Xavier Kieft, «L'autorité de l'argument. Note à propos de la Somme théologique, la pars, q. I, a. 8 », Questes [En ligne], 8 | 2006, mis en ligne le 01 janvier 2014, consulté le 02 mai 2019. URL : http:// journals.openedition.org/questes/1553; DOI : 10.4000/questes.1553

Ce document a été généré automatiquement le 2 mai 2019.

(C) Association des amis de «Questes » 


\section{L'autorité de l'argument. Note à propos de la Somme théologique, Ia pars, q. I, a. 8}

Xavier Kieft

\section{NOTE DE L'ÉDITEUR}

Cet article n'a pas encore fait l'objet d'une autorisation de publication.

\section{INDEX}

Keywords : authority, theology, doctrine, Thomas d'Aquin, philosophy, scholastic, speculation, Abelard

Mots-clés : autorité, théologie, doctrine, Thomas d'Aquin, philosophie, scolastique, spéculation, Abélard 